\title{
WAVE DISSIPATION MODELLING ON PILE BREAKWATER USING XBEACH
}

\section{PEMODELAN DISIPASI GELOMBANG PADA PEMECAH GELOMBANG TIANG PANCANG MENGGUNAKAN XBEACH}

\section{Eduardo Meyrianso Simanjuntak ${ }^{1)}$ Leo Eliasta ${ }^{1)}$ Juventus Welly Ginting1) Ida Ayu Irawati Diah Ratna Putra1)}

1) Balai Litbang Pantai, Puslitbang SDA, Jl. Gilimanuk - Singaraja, Gerokgak, Buleleng, Bali, Indonesia Email: eduardodevescounte@yahoo.com

Diterima: 15 Maret 2019; diperbaiki: 19 Juni 2019 ; disetujui: 25 Juni 2019

\begin{abstract}
ABSTRAK
Pemecah gelombang tiang pancang merupakan struktur pantai alternatif dalam mencegah erosi pantai dari aspek ekonomi dan teknis. Pengembangan desain dari penelitian sebelumnya dilakukan dalam penelitian ini. Tujuan kami adalah mengembangkan alat bantu perencanaan implementasi struktur pantai ini. Alat bantu ini berdasarkan model numerik yang telah diverifikasi dengan hasil model fisik. Spektrum gelombang menunjukkan bahwa model numerik dapat menyimulasikan gelombang dengan baik seperti model fisik meski terdapat overestimasi. Hal lainnya adalah noise ditemukan lebih signifikan untuk skenario dengan periode gelombang $(T)=2.5 \mathrm{~s}$ dibandingkan terhadap skenario dengan periode gelombang $(T)=2$ s. Secara umum, model numerik dapat memprediksi tinggi gelombang datang (Hi), tinggi gelombang transmisi (Ht), dan koefisien transmisi (KT) dengan eror kurang dari $1 \%$ RMSE. Xbeach dapat juga menyimulasikan pemecah gelombang tiang pancang dengan akurasi tinggi terutama untuk susunan dua atau tiga baris dengan lebar celah $0.3 \mathrm{~m}$. Meskipun begitu, model numerik masih memiliki keterbatasan berkaitan dengan fasa gelombang dan ketidakteraturan lembah gelombang.
\end{abstract}

Kata Kunci : Model fisik, tinggi gelombang transmisi, koefisien transmisi, tiang pancang, Xbeach

\begin{abstract}
Pile breakwater is an alternative coastal structure to prevent coastal erosion considering the economic and technical aspect. An improved design for pile breakwater is proposed here. Our goal is to develop an assessment tool in planning the implementation of pile breakwater. This tool is based on numerical model that has been verified with physical model result. The wave spectrum show that the numerical model is able to simulate the wave as same as the physical model with overestimation. It also points out that the simulation with wave period $(T)=2.5 \mathrm{~s}$ has more significant noise than the simulation with wave period $(T)=2 \mathrm{~s}$. In general, the numerical model has high accuracy for predicting incident wave height (Hi), transmitted wave height (Ht) and transmission coefficient (KT) with error below $1 \%$ RMSE. Xbeach is also able to simulate pile breakwater with high accuracy especially for two or three row arrangement with width gap $0.3 \mathrm{~m}$. Even so, the numerical model have limitation regarding wave phase and wave through irregularity.
\end{abstract}

Keyword : Physical model, transmitted wave height, transmission coefficient, pile breakwater, Xbeach

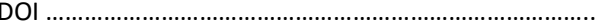

(C) Puslitbang SDA, Balitbang, Kementerian PUPR Naskah ini di bawah kebijakan akses terbuka dengan lisensi

CC-BY-SA (https://creativecommons.org/licenses/by-sa/4.0/) 


\section{INTRODUCTION}

One of the common solutions for coastal erosion is breakwater. This structure is able to reduce the wave height significantly. This study investigate pile breakwater as an alternative design for the conventional which is made of rubble. The investigation is conducted by modelling wave dissipation due to pile breakwater using numerical model. The result is then verified by physical experiment data. The developed numerical model can be used as an assessment tool for planning the implementation of pile breakwater in the field.

Hayashi et al (1966) study transmitted wave of the closely spaced pile breakwater. The investigation compares the transmitted wave in the closely spaced pile breakwater to the nonspaced pile breakwater. This comparison shows the relationship between the space between pile and the transmitted wave. The increased space between pile generate the decreasing of transmitted wave in considerable rate. The study conclude that we can calculate the most optimized engineering solution considering the economic aspect.

Rao et al (2002) continue the study about the closely spaced pile breakwater with more complex configuration. Pile breakwater is arranged in two row formation as opposed to one row formation in Hayashi et al (1966). In addition, piles are formed in a staggered way. Another complexity added to this research is the usage of perforated pile. With $\mathrm{D}$ is diameter, the result highlights the influence of relative clear spacing between the pile in a row (b/D) and relative clear spacing between the pile rows (B/D) for transmitted wave coefficient (KT) and reflected wave coefficient (KR). Kt is decreasing when $b / D$ is decreasing. As for $K R$, there is no consistent relationship with $b / D$. In contrary, the relationship between $\mathrm{KR}$ and $\mathrm{B} / \mathrm{D}$ is very clear. KR is decreasing steadily while $B / D$ is increasing in respective of $b / D$ values. The mentioned results before also vary for different incident wave steepness $\left(\mathrm{Hi} / \mathrm{gT}^{2}\right)$. Another important result is that staggered arrangement has significant impact in reducing KR.

This research developed pile breakwater design based in Rao et al (2002) with some modification. The design considers staggered arrangement for two and three row formation and variation of $B / D$ and $b / D$ values without using perforated pile. New design is introduced in this study by adding pile breakwater gap (G).. There are two gaps separate three blocks of piles (Figure 1 ). The effect of open gap against tsunami wave has been studied previously by Ba Thuy et al (2009) with different evaluation method.

The structure is also tested for different variation of wave height $(\mathrm{H})$ and wave period $(\mathrm{T})$. The interaction between the designed pile breakwater and the incident wave is modelled with physical experiment and numerical model. We use the experiment result to verify the numerical model, called Xbeach developed by van Rooijen et al (2015) for vegetation wave dissipation. A comprehensive endeavour to develop numerical for pile breakwater has been previously done by Suh and Shin (2006). The author use eigen function expansion method for the regular wave. Later, the regular wave model is used repeatedly for the irregular wave spectrum. Some vegetation parameter need calibration to obtain better result as suggested by Suzuki et al (2002). This paper only discuss the result for pile breakwater with three rows formation. As for the two-row formation, the result is already discussed in another paper (Simanjuntak et al, 2019).

\section{METHODOLOGY}

The physical experiment is conducted in wave flume of $40 \mathrm{~m}$ length and $3 \mathrm{~m}$ width (Figure 1 ). The model set-up is designed with slope of 1:40 at approximately $8 \mathrm{~m}$ from the wave generator with the rest is in constant depth water of $0.4 \mathrm{~m}$. There are 8 wave probes (P1, P2,..., P8) in wave flume used in this experiment. In addition, there is also measurement of current velocity using ADV (Acoustic Doppler Velocimeter) but not discussed here. We reproduce the same condition for the numerical model, Xbeach. It is developed based on Jansen and Battjes (2007) which calculate the shortwave dissipation by wave breaking. We prepare the numerical model set-up with the help of DELFT RFGRID and QUICKIN. The grid size used in the numerical model is $0.05 \mathrm{~m} \times 0.05 \mathrm{~m}$.

Pile breakwater is located at approximately $30 \mathrm{~m}$ from the wave generator. There are five parameters for pile breakwater. First, pile diameter (D). Second, pile height (ah). Third, pile breakwater gap (G). Fourth, relative spacing between pile in a row (b/D). Last, relative clear spacing between the pile rows (B/D). All these parameters can be accommodated in Xbeach with some adaptation. There are two important file input related to the vegetation module. First, the vegetation map. We can describe pile breakwater position in the model grid as bathymetry file using DELFT QUICKIN. Grid without pile is defined as depth value of 0 and grid with pile is defined as depth value 1 (Figure 2). This way, we are also able to define the pile gap (G) with precision depending on the model grid. Since the pile 
position is designed in a staggered way in three formation with relative spacing (b/D) and (B/D), the numerical model do not accommodate this directly (Figure 3).

This design is adapted in the model by calibrating the vegetation properties in another file. Figure 4 describe the vegetation properties in Xbeach vegetation module. There are five vegetation properties. First, nsec which is $n$ number of vertical layers in the vegetation that represent root, stem and branch. Each section has its own properties. But, all of them is assumed as cylinder. So, since we want to use this module for cylinder pile, we input nsec $=1$. The second is ah which represent the relative pile height to the water depth. In this case, we input $\mathbf{a h}=1 \mathrm{~m}$. The keyword bv is for the pile diameter (D) which is $0.06 \mathrm{~m}$. The last two vegetation properties are vegetation density per area unit (N) and drag coefficient (Cd). We calculate $\mathrm{N}$ that is influenced by structure parameter G, B/D and b/D then input it to the numerical model. The staggered design is also related to the vegetation density. Parameter $\mathrm{N}$ will not represent $\mathrm{B} / \mathrm{D}, \mathrm{b} / \mathrm{D}$ and staggered arrangement precisely. So, we calibrate drag coefficient to attain the wave transmission more accurately.

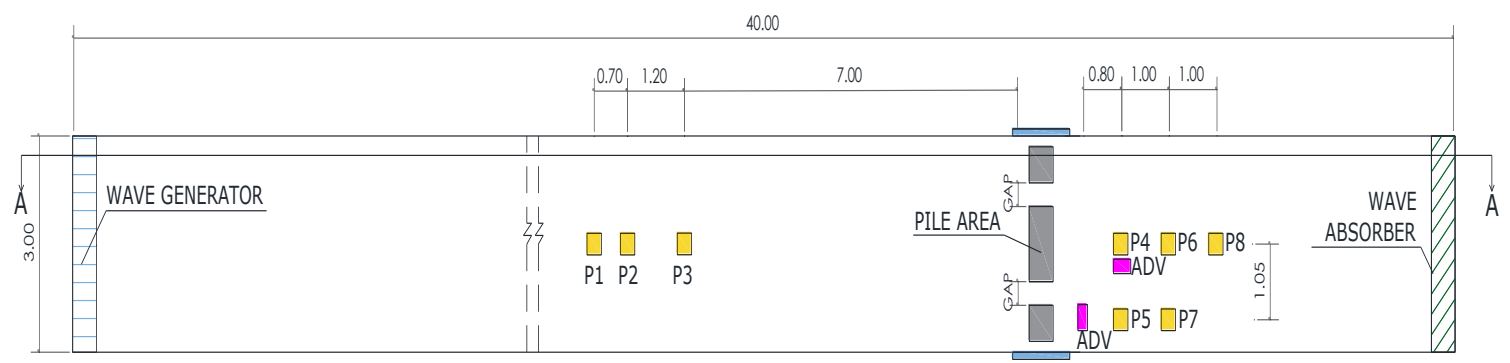

(a)

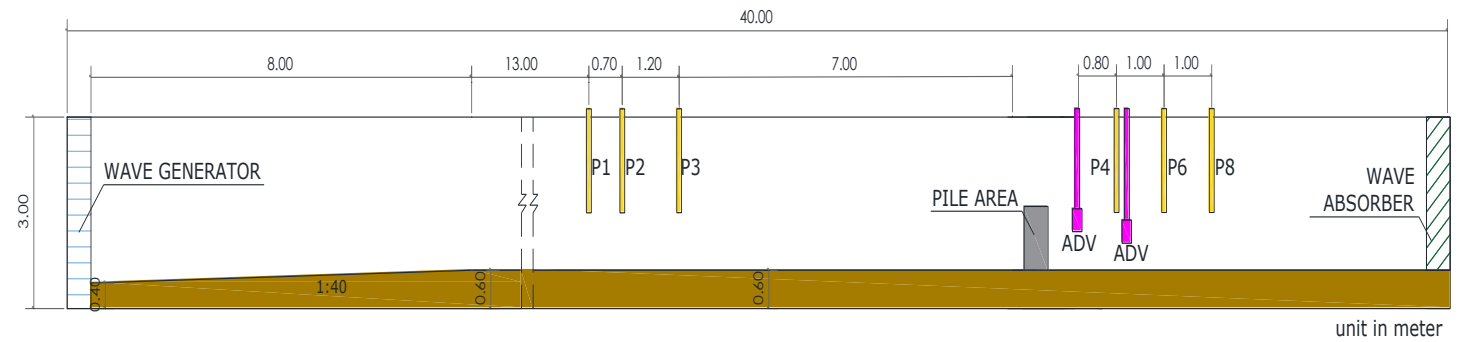

(b)

Figure 1 Overview of the wave flume setup including the location of piles and wave probes: top view (a) and A-A cross section (b)
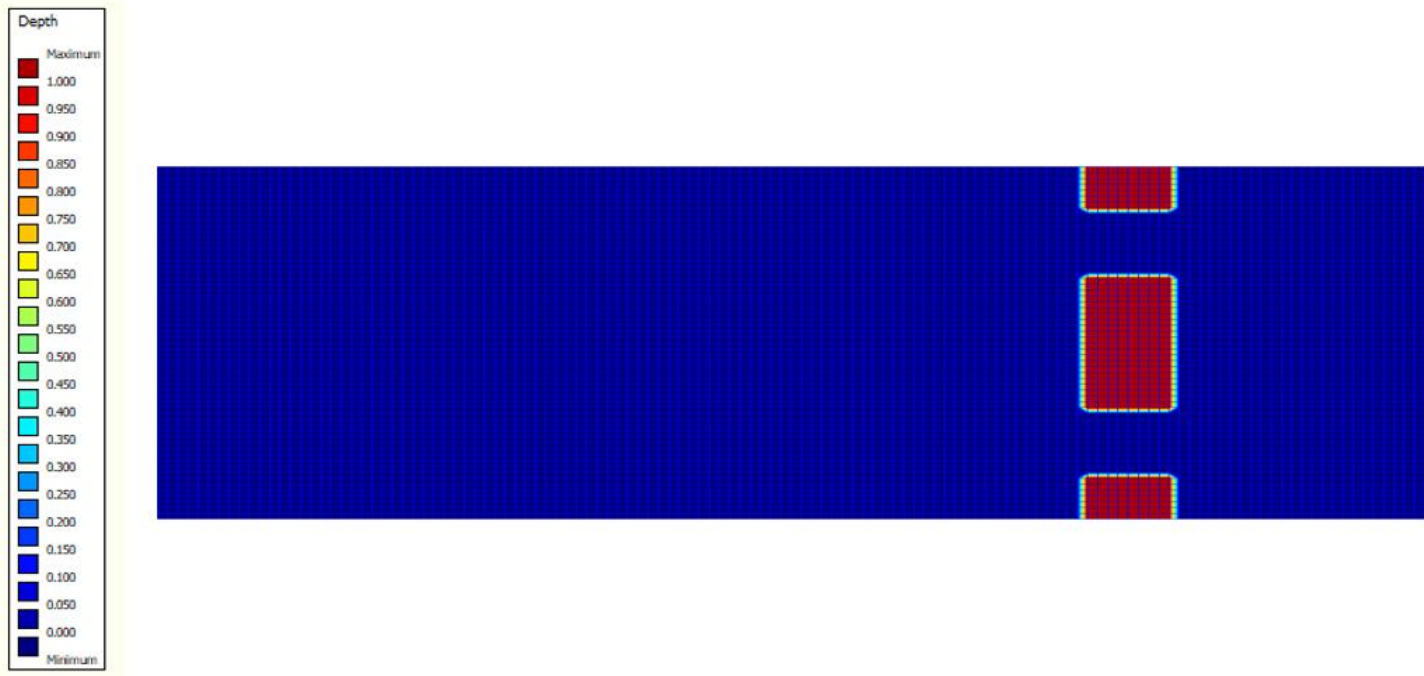

Figure 2 Vegetation map in Xbeach model made with QUICKIN DELFT3D 
The vegetation properties are variables in the equation of wave dissipation due to vegetation. The dissipation per vegetation layer $\left(D_{v, i}\right)$ in $X$ Beach is

$D_{v, i}=A_{v} \frac{\rho C_{D, i} b_{v, i} N_{v, i}}{2 \sqrt{\pi}}\left(\frac{g k}{2 \sigma}\right)^{3} H_{r m s}{ }^{3}$

with

$A_{v}=\left[\left(\sinh ^{3} k \alpha_{i} h-\sinh ^{3} k \alpha_{i-1} h\right)+3\left(\sinh ^{3} k \alpha_{i} h-\right.\right.$ $\left.\left.\sinh ^{3} k \alpha_{\mathrm{i}-1} \mathrm{~h}\right)\right] /\left(3 \mathrm{k} \cosh ^{3} \mathrm{kh}\right)$

where $C_{D, i}$ is drag coefficient, $b_{v, i}$ is the vegetation stem diameter, $N_{v, I}$ is the vegetation density and $\alpha_{i}$ is the relative vegetation height $\left(=h_{v} / h\right)$ for layer i. If there is only layer ( $\mathrm{i}=1)$, it is assumed the vegetation is uniform vertically as in the case of seagrass.

Pile breakwater is tested for variation of incident wave steepness $\left(\mathrm{Hi} / \mathrm{gT}^{2}\right)$. $\mathrm{P} 1$ and $\mathrm{P} 4$ are the reference wave probe for incident wave and transmitted wave respectively for both the numerical and physical model. The wave parameter can be input directly into numerical model with keyword provided by Xbeach.

In general, there are six scenarios. Each pile breakwater has the same value for ah $(=1 \mathrm{~m}), \mathrm{D}(=$ $0.06 \mathrm{~m}), \mathrm{B} / \mathrm{D}(=1)$ and $\mathrm{b} / \mathrm{D}(=1)$. Every scenario differs in wave height $(\mathrm{H})$, wave period $(\mathrm{T})$ and pile gap (G) as shown in Table 1 . Incident wave height in numerical model will be calibrated to approach the experiment result. As for transmitted wave height, we calibrate the drag coefficient (Cd). Therefore, we can obtain transmission coefficient (KT) with low error. In this study, we only evaluate numerical model performance to simulate wave transmission. Xbeach vegetation module is not developed to simulate wave reflection. The staggered arrangement also helps to reduce wave reflection. Therefore, the noise due to wave reflection can be minimized.

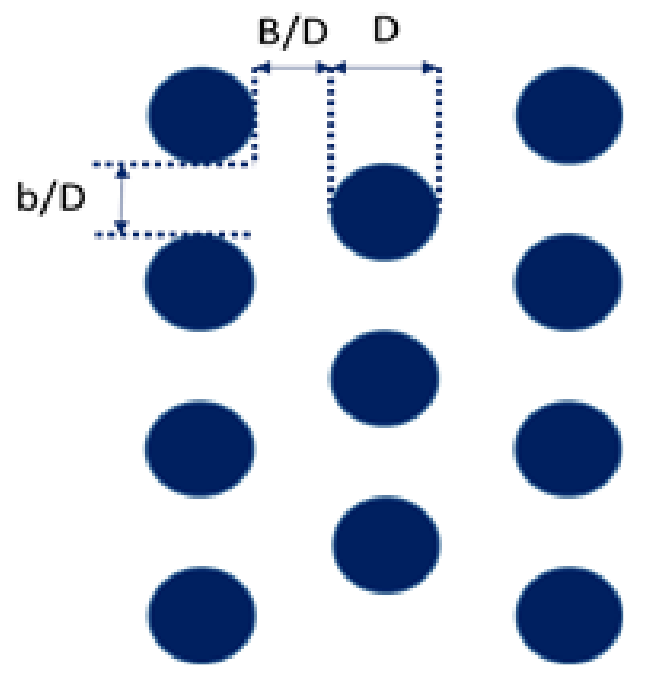

Figure 3 Staggered piles in three row formation

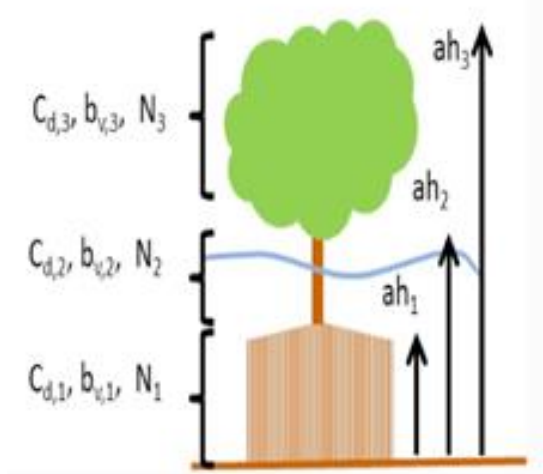

Source: Roelvink et al, 2015

Figure 4 Definition sketch for vegetation properties 
Table 1 Model Scenario with Variation of Wave Height, Wave Period and Pile Gap

\begin{tabular}{ccccc}
\hline No. & Scenario & $\mathrm{H}(\mathrm{m})$ & $\mathrm{TP}(\mathrm{s})$ & Gap (m) \\
\hline 1 & SN01 & 0.15 & 2.0 & 0.3 \\
2 & SN02 & 0.2 & 2.5 & 0.3 \\
3 & SN03 & 0.15 & 2.0 & 0.5 \\
4 & SN04 & 0.2 & 2.5 & 0.5 \\
5 & SN05 & 0.15 & 2.0 & 0.58 \\
6 & SN06 & 0.2 & 2.5 & 0.58 \\
\hline
\end{tabular}

\section{RESULTS AND DISCUSSION}

The water elevation of wave probe 1 and wave probe 6 is shown in Figure 5 and Figure 6 respectively for both the physical model and the numerical model. Wave probe 1 represents incident wave in front of the structure while water elevation behind the structure is found in wave probe 6 . Figure 5 shows the water elevation from $75 \mathrm{~s}$ to $105 \mathrm{~s}$ after the initial time. The numerical model successfully reproduce the wave with close resemblance to the physical model result. The similarity is found in the wave height and the wave steepnes. Although, distinguished feature such as wave form and wave phase is significantly different between the numerical model and the physical model. Model scenario SN01, SN05 and SN06 have fitted result of wave phase as the others have considerable different wave phase between the numerical model and the physical model. The difference is probably due to the different initial condition or the superposition of incident and reflected wave. As for the latter case, Xbeach has limitation to calculate the reflected wave. So, the reflected wave is not take into account in the numerical model. Although, we are able to separate the wave reflection influence in the laboratory data, Mansard and Funke (1980) method is only possible for the wave height not the wave phase. The second feature which is different between these two models is the wave form. As we can see, the wave through in the laboratory result is irregular. This is possible due to noise during the data acquisition. This noise is eventhough significant but is not possible to be reproduced in the numerical model, Xbeach.

The water elevation behind structure is simulated with overestimation of the wave height (Figure 6). The figure shows that the overestimation is more significant for the wave crest amplitude than the wave through amplitude. The wave through of the physical model also have irregular form. This irregularity is perhaps due to turbulence behind the structure as the result of the interaction between the wave and the pile breakwater. The wave phase seems only fit between these two models for model scenario SN01, SN05 and SN06.

Figure 7 shows incident wave spectrum for each scenario. There are two or three wave spectrum with different level of peak energy in every figure. The one with the highest peak energy level is categorized as the main spectrum while the others are the wave spectrum due to noise. Incident wave spectrum for SN02, SN04 and SN06 show there are two spectrum due to noise. It indicates that physical model produce more significant noise during the simulation for wave period $(\mathrm{T})=2.5 \mathrm{~s}$ than the simulation with $\mathrm{T}=2 \mathrm{~s}$. For the main spectrum, the numerical model overestimates the peak energy level in each scenario. The error seems significant. But, this is still acceptable since the time series for both the experiment and the numerical model are not yet corrected for the wave reflection. The wave spectrum for the corrected time series is not availaible because Mansard and Funke (1980) method is limited for such purpose. The method can only provide the corrected significant wave height in front of the structure. In this case, we call it the incident wave height (Hi) in the reference wave probe P1. The wave reflection correction is only for the experiment. It is not necessary for the numerical model since Xbeach vegetation is not developed to simulate wave reflection. In general, we can consider Xbeach is able to simulate the interaction between the wave and pile breakwater with reasonable error.

The transmitted wave spectrum shows the same pattern as the incident wave spectrum. There are the main spectrum and the noise spectrum. The main spectrum shows overestimation by the numerical model. This is also the case for the noise spectrum. Turbulence due to the wave transmission screening through pile breakwater possibly cause this noise. 

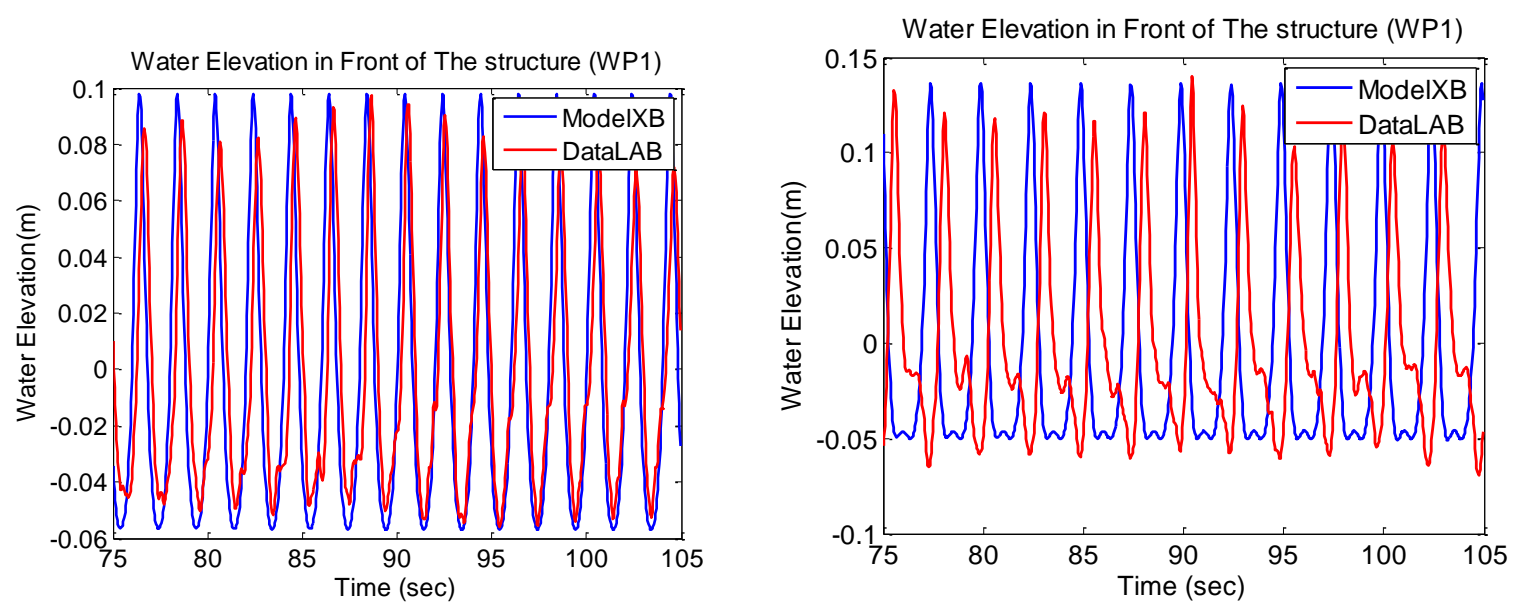

(a)

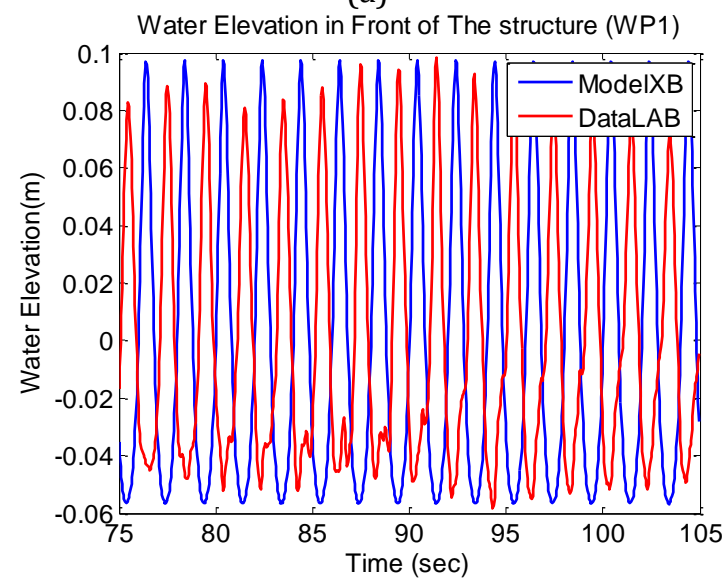

(b)

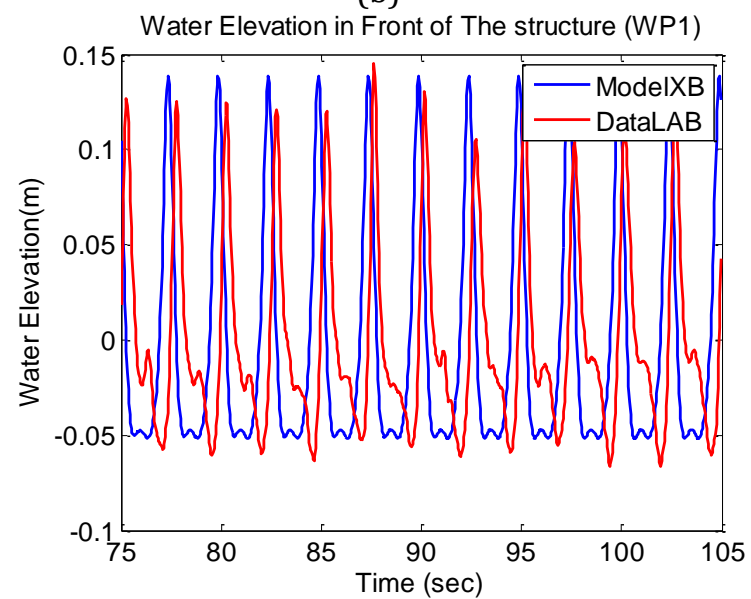

(c)

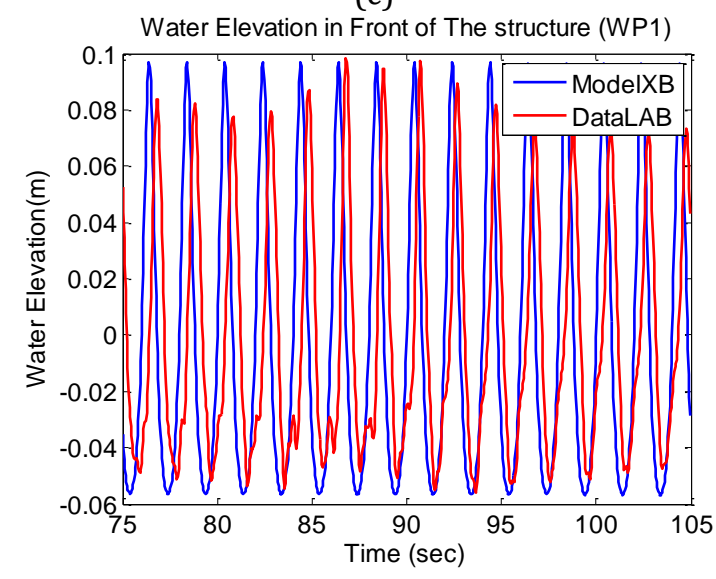

(e)

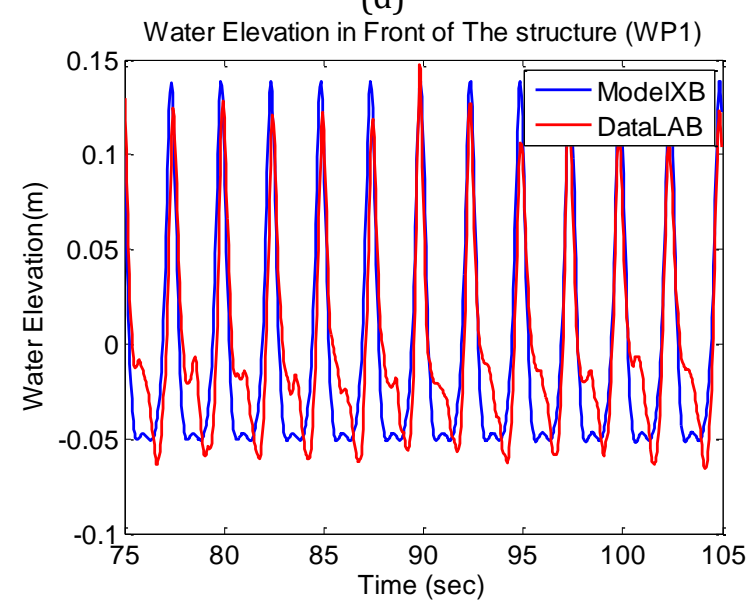

(f)

Figure 5 Water level in wave probe 1 for (a) SNO1, (b) SNO2, (c) SNO3, (d) SNO4, (e) SNO5 and (f) SNO6 

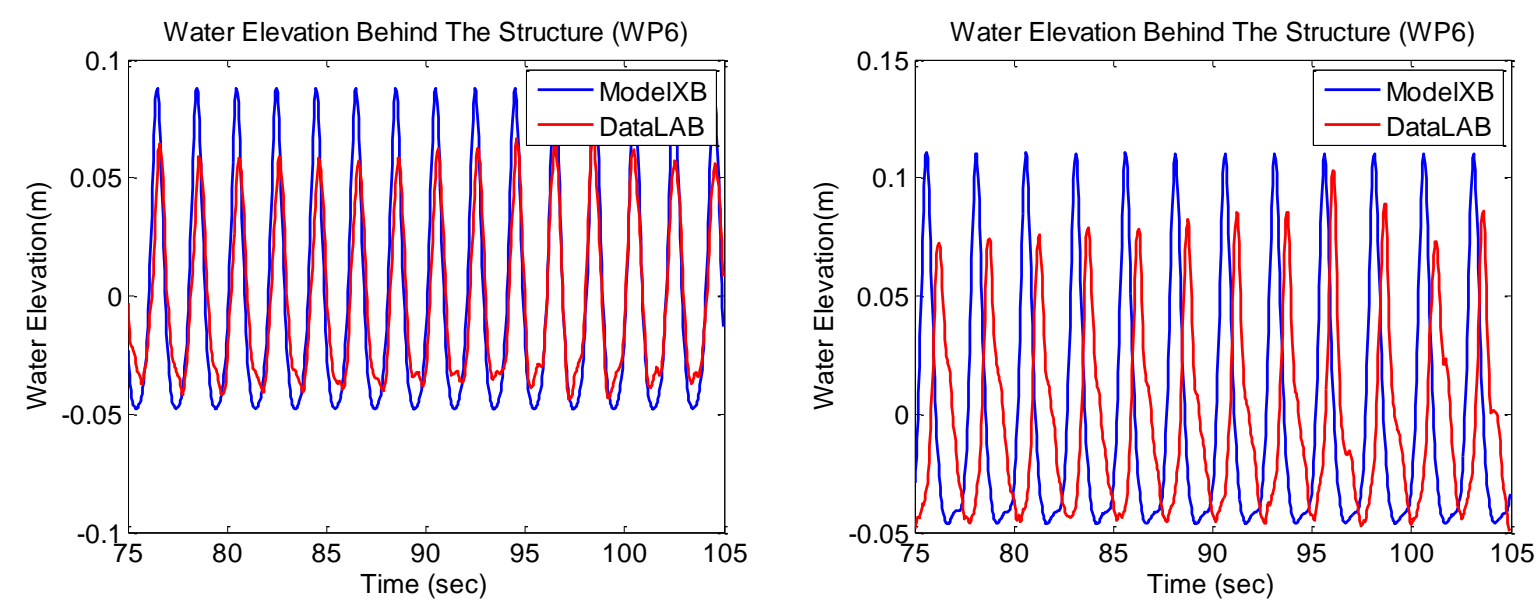

(a)

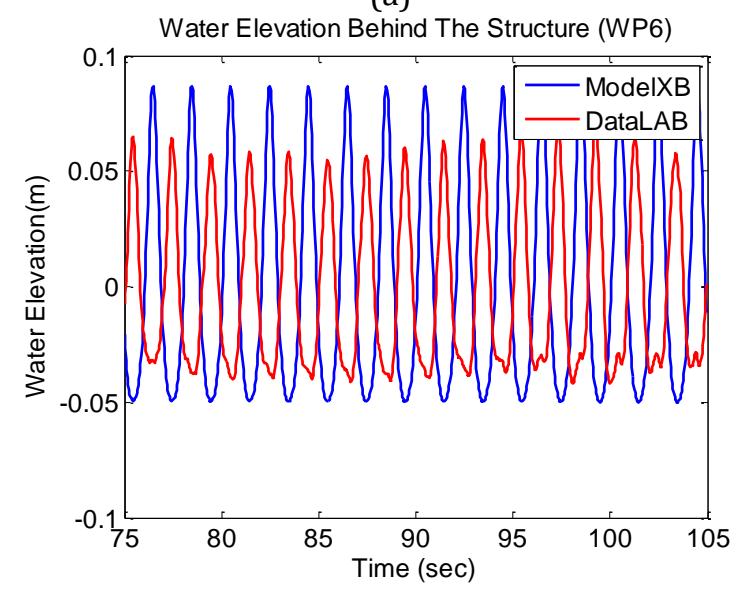

(b)

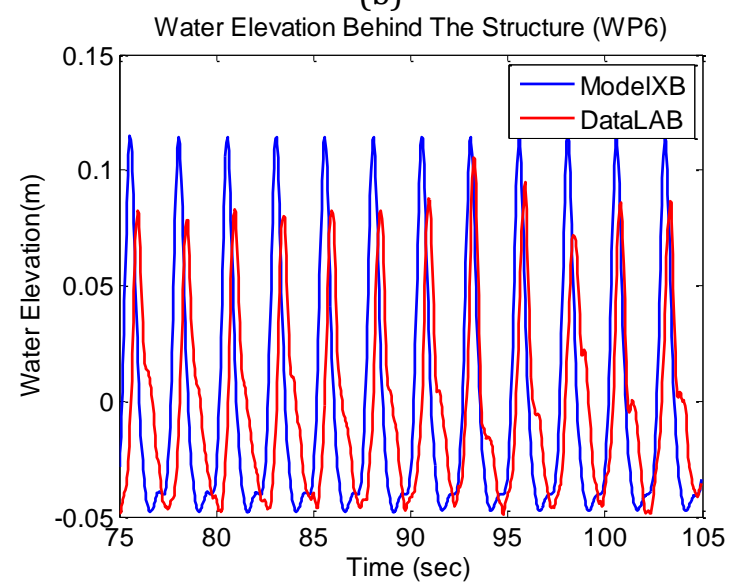

(c)

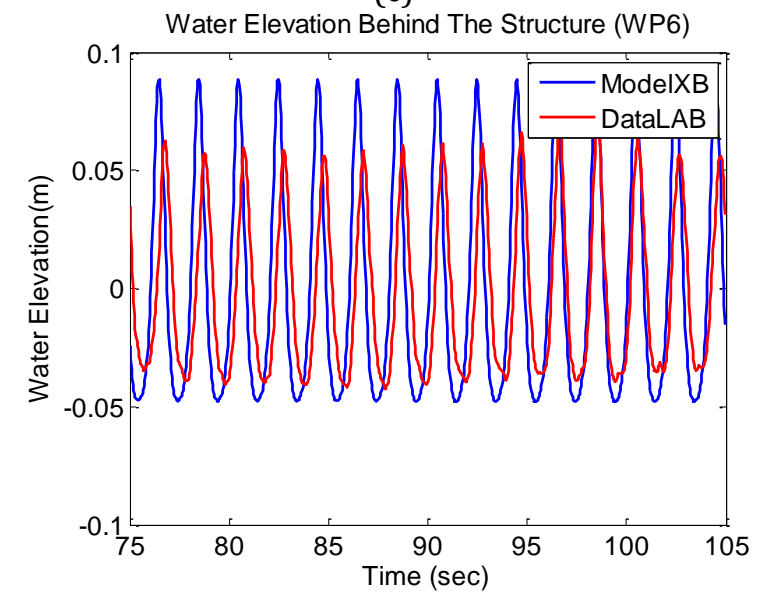

(e)

(d)

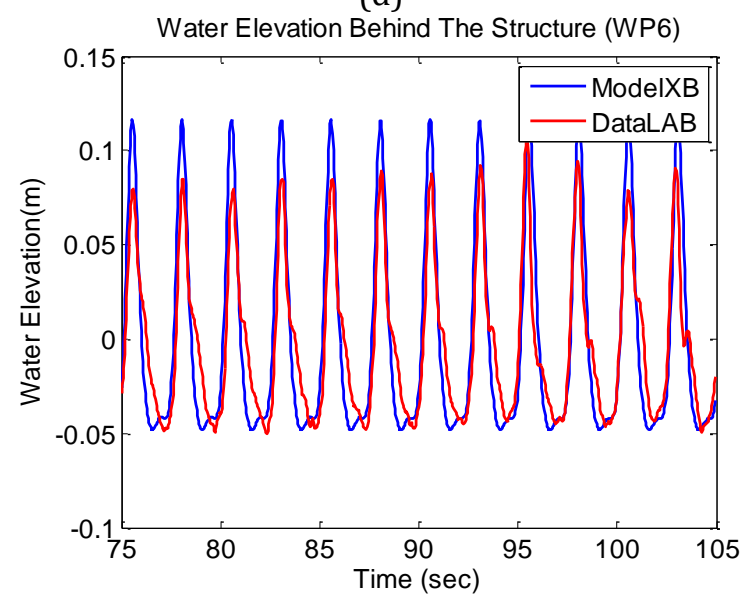

(f)

Figure 6 Water level in wave probe 4 for (a) SN01, (b) SN02, (c) SN03, (d) SN04, (e) SN05 and (f) SN06 


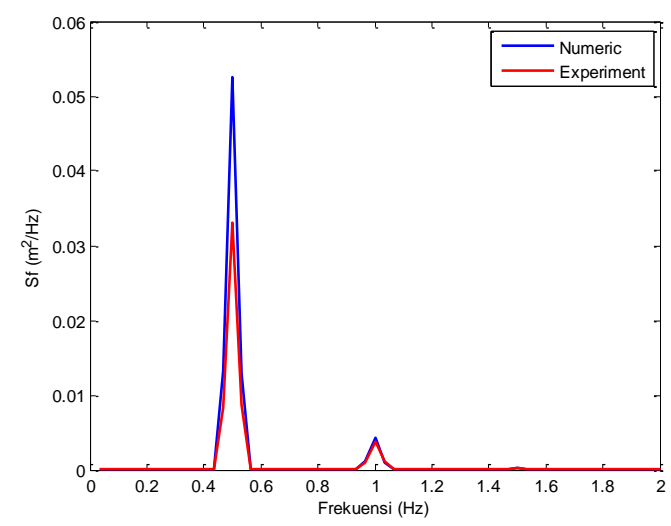

(a)

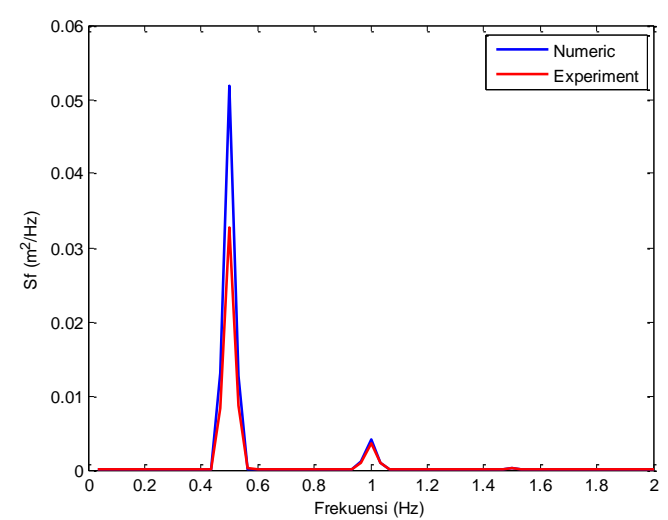

(c)

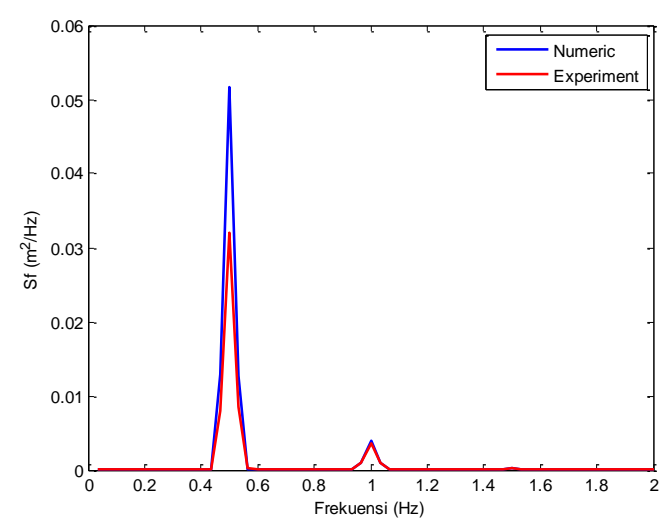

(e)

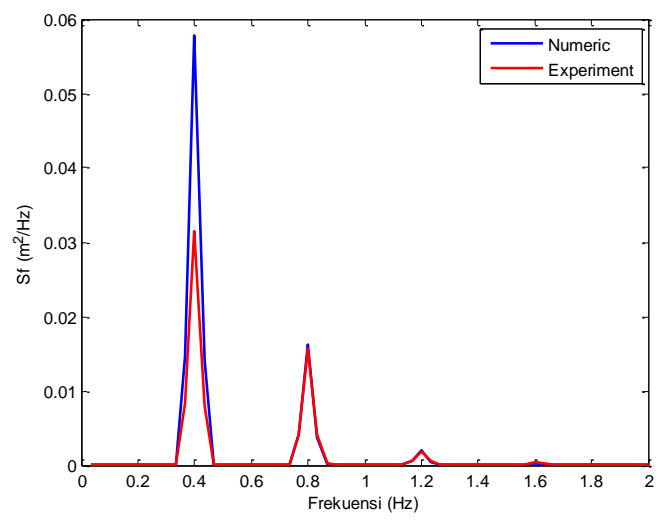

(b)

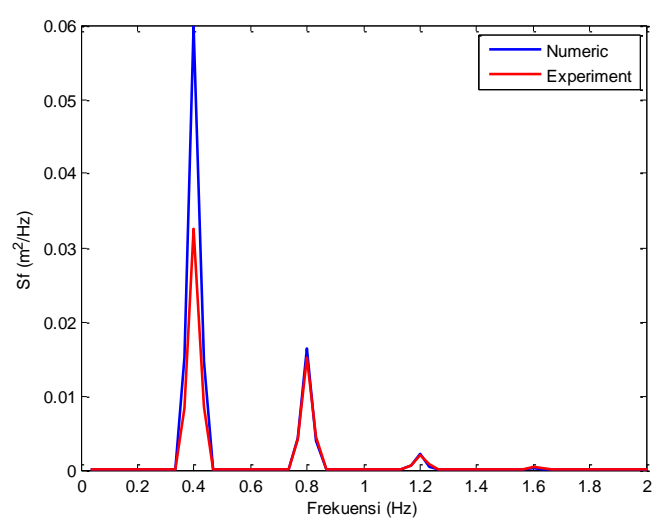

(d)

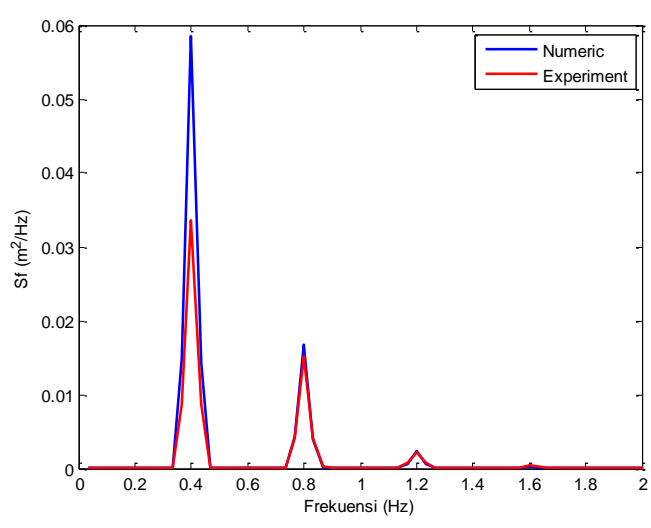

(f)

Figure 7 Incident wave spectrum for (a) SN01, (b) SNO2, (c) SNO3, (d) SNO4, (e) SNO5 and (f) SNO6 


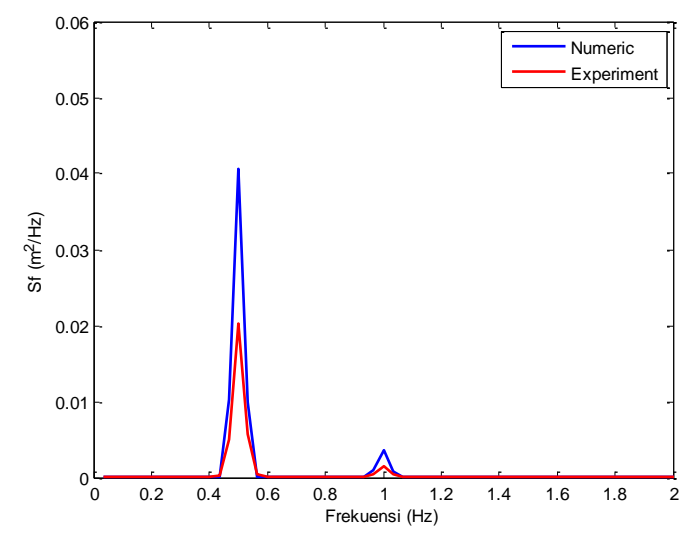

(a)

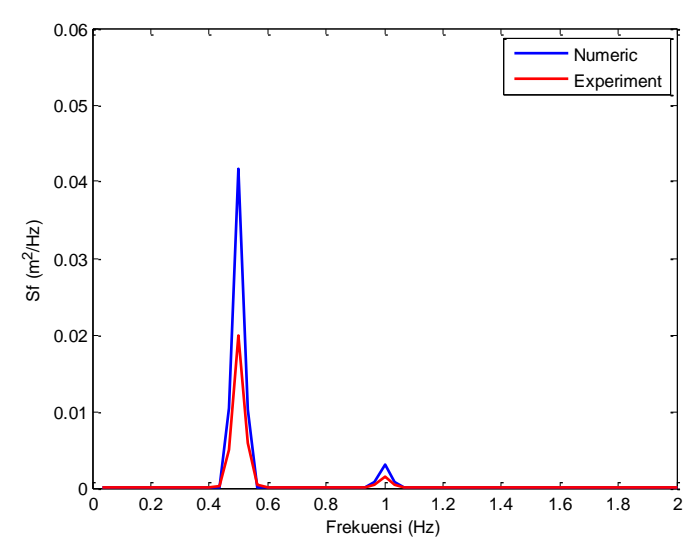

(c)

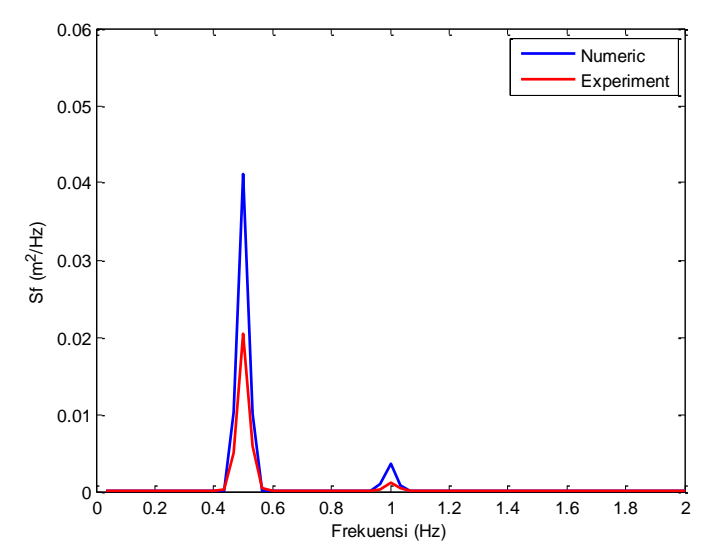

(e)

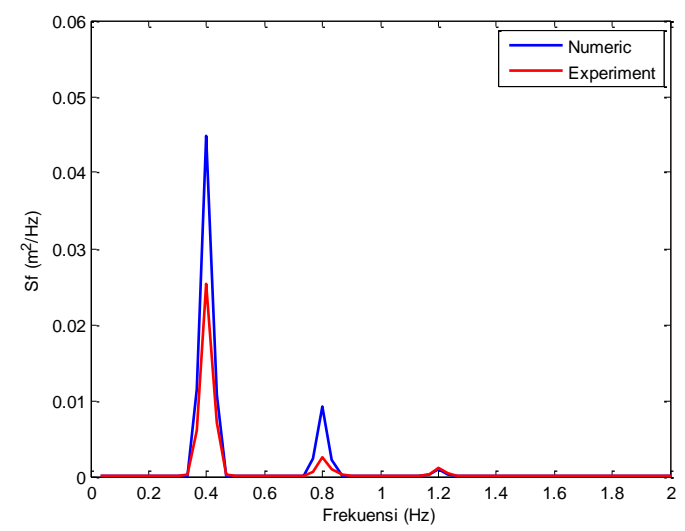

(b)

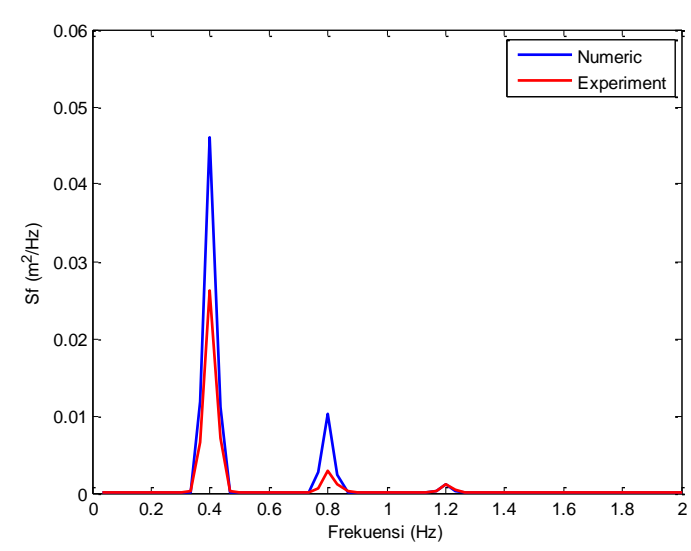

(d)

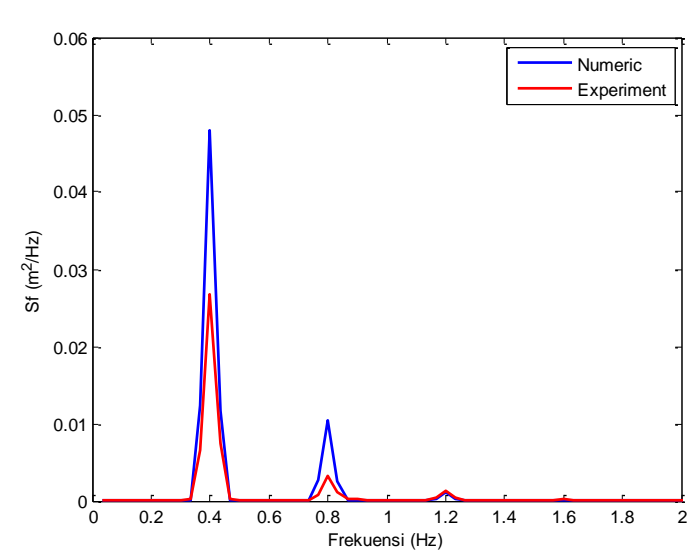

(f)

Figure 8 Transmitted wave spectrum for (a) SN01, (b) SN02, (c) SN03, (d) SN04, (e) SN05 and (f) SN06

For $\mathrm{Hi}$, we are able to improve model performance by calibrating the initial wave height (H) input in model. Table 2 shows the incident wave height for both the experiment and the numerical result. In general, model can predict $\mathrm{Hi}$ with error only $0.1627 \%$ RMSE (Root Mean
Square Error). The numerical model achieves the lowest error for SN03 with $0.0510 \%$ NE (Normalized Error) weighing in the experiment data. The highest error is found in SN04 with $0.2371 \% \mathrm{NE}$. 
Table 3 shows transmitted wave height for both the experiment and the numerical model. SN03 has the highest error with $2.3478 \%$ NE whilst the numerical model is able to simulate with the highest accuracy for SN06. The error is only $0.0322 \%$ NE. For the whole scenario, we can conclude that the model accuracy for transmitted wave height prediction is about $0.9750 \%$. Transmitted wave spectrum presented in Figure 6 also show the same characteristic as incident wave spectrum. The numerical model overestimates the peak energy of main spectrum. Another similar feature is that simulation with $\mathrm{T}=$ $2.5 \mathrm{~s}$ producing more noise than the one with $\mathrm{T}=$ $2 \mathrm{~s}$.

For transmission coefficient (KT), the numerical model is able to perform with high accuracy (Table 4). The model error is only $0.9881 \%$ RMSE. SN01 has the lowest error while SN03 has the highest error. It seems that the model is only able to achieve $\mathrm{KT}=0.8874$ for given scenario as we need to reach KT experiment = 0.9090. This is similar to the case in Simanjuntak et al (2019). The numerical model is only able to reach $\mathrm{KT}=0.8904$ while $\mathrm{KT}$ experiment is 0.9004 .
Simanjuntak et al (2019) conclude that this paticular case is due to the numerical model limitation. But, we propose different argument here. The notion of wave steepness is perhaps a possible explanation. Pile breakwater in this research has the same arrangement as that of Simanjuntak et al (2019): pile height $(\mathrm{ah})=1 \mathrm{~m}$, the relative spacing between pile in a row $(b / D)=$ 1 and the relative spacing between pile in a row $(\mathrm{B} / \mathrm{D})=1$ and diameter $(\mathrm{D})=0.06 \mathrm{~m}$. The only difference is that pile breakwater in this research is arranged in three row staggered formation whilst Simanjuntak et al (2019) only has two row. The highest error in both research is found in model scenario with $\mathrm{H}=0.15 \mathrm{~s}$ and $\mathrm{T}=2 \mathrm{~s}$. The wave steepness seems to affect the numerical model result. Simulation with higher steepness wave $(=0.0038)$ have highest error. In two row formation, it is for simulation with width gap $(G)=$ $0.58 \mathrm{~m}$ whilst it happens only for $\mathrm{G}=0.5 \mathrm{~m}$ in three row staggered pile breakwater. Either way, the width gap $(G)=0.3 \mathrm{~m}$ is reccomended for either the two or the three row staggered arrangement of pile breakwater simulation with Xbeach.

Table 2 Incident Wave Height Result for the Experiment and the Numerical Model Result

\begin{tabular}{ccccc}
\hline No & Scenario & Hi $\operatorname{Exp}(\mathrm{m})$ & Hi Num $(\mathrm{m})$ & NE $(\%)$ \\
\hline 1 & SN01 & 0.1550 & 0.1553 & 0.1983 \\
2 & SN02 & 0.1887 & 0.1884 & 0.2037 \\
3 & SN03 & 0.1541 & 0.1542 & 0.0510 \\
4 & SN04 & 0.1913 & 0.1918 & 0.2371 \\
5 & SN05 & 0.1533 & 0.1538 & 0.1244 \\
6 & SN06 & 0.1915 & 0.1914 & 0.0604 \\
\hline
\end{tabular}

Table 3 Transmitted Wave Height Result for The Experiment and The Numerical Model Result

\begin{tabular}{|c|c|c|c|c|}
\hline No & Scenario & $\mathrm{Ht} \operatorname{Exp}(\mathrm{m})$ & Ht Num (m) & NE (\%) \\
\hline 1 & SN01 & 0.1360 & 0.1357 & 0.1965 \\
\hline 2 & SN02 & 0.1576 & 0.1578 & 0.1195 \\
\hline 3 & SN03 & 0.1401 & 0.1368 & 2.3478 \\
\hline 4 & SN04 & 0.1623 & 0.1628 & 0.2885 \\
\hline 5 & SN05 & 0.1366 & 0.1363 & 0.2333 \\
\hline 6 & SN06 & 0.1644 & 0.1643 & 0.0322 \\
\hline
\end{tabular}


Table 4 Transmission Coefficient Result for The Experiment and The Numerical Model Result

\begin{tabular}{ccccc}
\hline No & Scenario & KT Exp $(\mathrm{m})$ & KT Num $(\mathrm{m})$ & NE (\%) \\
\hline 1 & SN01 & 0.8734 & 0.8734 & 0.0019 \\
2 & SN02 & 0.8348 & 0.8375 & 0.3239 \\
3 & SN03 & 0.9090 & 0.8874 & 2.3710 \\
4 & SN04 & 0.8483 & 0.8487 & 0.0513 \\
5 & SN05 & 0.8893 & 0.8861 & 0.3572 \\
6 & SN06 & 0.8581 & 0.8584 & 0.0281 \\
\hline
\end{tabular}

In general, the numerical model is able to simulate the incident wave with high accuracy for the wave height and wave steepness. As for the transmitted wave, the numerical model overestimate the wave height. Even so, there are limitations for the wave to accommodate irregularities and wave phase. But, this result is promising. We still need to test the model for other variations of pile breakwater design. With further development, the adapted Xbeach is ready to develop an assessment tool in planning pile breakwater implementation.

\section{CONCLUSION}

The interaction between the wave and pile breakwater is simulated by numerical model with high accuracy. This is shown by the similarity between wave spectrum of both the experiment and the numerical error. Even though the numerical model overestimates the peak energy in the main spectrum and there are significant noises, this is still acceptable since the spectrum represent the raw data. A better representation of model performance is comparing the significant wave height between the experiment and the numerical model. It can predict incident wave height (Hi) with RMSE percentage of $0.1627 \%$. This accuracy is achieved through calibrating the wave height input. The numerical model is also able to simulate transmitted wave height $(\mathrm{Ht})$ with only RMSE percentage of 0.9750 . By comparing $\mathrm{Hi}$ and $\mathrm{Ht}$, we can calculate that the error between the experiment and the numerical model is only $0.9881 \%$ of RMSE percentage. The numerical model is also able to simulate pile breakwater with high accuracy especially for two or three row arrangement with width gap $0.3 \mathrm{~m}$. Even so, the numerical model have limitation regarding wave phase and wave through irregularity. Still, this adapted numerical model shows promising performance that will advance the development of assessment tool for pile breakwater implementation.

\section{ACKNOWLEDGEMENT}

The author wishes to acknowledge the laboratory technician and principal scientist in The Experimental Station of Coastal Engineering, Research Center for Water Resources, Ministry of Public Works and Housing, Republic of Indonesia for their hard work during this research.

\section{REFERENCES}

Ba Thuy, N., K.Tanimoto, N.Tanaka, K. Harada, and K. Iimura. 2009. Effect of open gap in coastal forest on tsunami run-up- investigation by experiment and numerical simulation. Journal of Ocean Engineering Vol. 36 : 1258-1269

Hayashi, T., M. Hattori, T.Kano, and M. Shirai. 1966. Hydraulic Research on the closely spaced pile breakwater. Coastal Engineering in Japan. Vol. 9 (1): 107-117.

Janssen, T.T and J.A. Battjes. 2007. A note on wave energy dissipation over steep beaches. Journal of Coastal Engineering vol. 54 (9) : 711-716

Mansard, E.P.D and E.R Funke. 1980. The measurement of incident and reflected spectra using a least square method. Journal of Coastal Engineering : 154-172.

Rao, S. K.G. Shirlal and N.B.S Rao. 2002. Wave transmission and reflection for two rows of perforated hollow piles. Indian Journal of Marine Sciences Vol.31 (4) : 283-289.

Roelvink, D.J.A, A van Dongeren, R.T. McCall and B. Hoonhut. 2015. Xbeach Technical Reference: Kingsday Release. DOI: 10.13140/RG.2.1.4025.6 244 
Simanjuntak, E.M, A.A Laksmi, J.W.R Ginting, I.A.I.D.R Putra, L.Eliasta, H.Bachtiar and A.Prasetyo. 2019. Investigation of wave dissipation for pile breakwater using computational and physical model. Proceeding of INTAKINDO International Conference on Construction Technology and Innovation 2019.

Suh, K-D., S.Shin, and D.T. Cox. 2014. Hydrodynamic characteristic of pilesupported vertical wall breakwater. Journal od Waterway, Port, Coastal and Ocean Engineering Vol.132 (2) : 83
Suzuki, T., M.Zijlema, B.Burger, M.C Meijer, S.Narayan. 2002. Wave dissipation by vegetation with layer schematization in SWAN. Journal of Coastal Engineering (59) : 64-71.

van Rooijen, A.A, J.S.M van Thiel de Vries, R.T McCall. A.R van Dongeren, J.A Roelvink, A.J.H.M Reniers. 2015. Modelling of wave attenuation by vegetation with Xbeach. Paper presented at the $36^{\text {th }}$ IAHR World Congress. http://resolver.tudelft.nl/uuid:98a66b958fed-421a-9bfe-4ae978375dbe

\section{Attachment : Xbeach model set-up}

\#Params.txt (master file to execute the model)

\% Non hydrostatic boundary generation

wavemodel $=$ nonh

\% Flow boundary condition parameters

front $=$ wall

$\operatorname{arc}=1$

back = abs_2d

left $\quad=$ wall

right = wall

\% Flow numerics parameters

eps $=0.005000$

$\mathrm{hmin}=0.010000$

$\%$ Flow parameters

$\mathrm{cf}=0.003$

smag $=1$

nuh $=0.15$ 


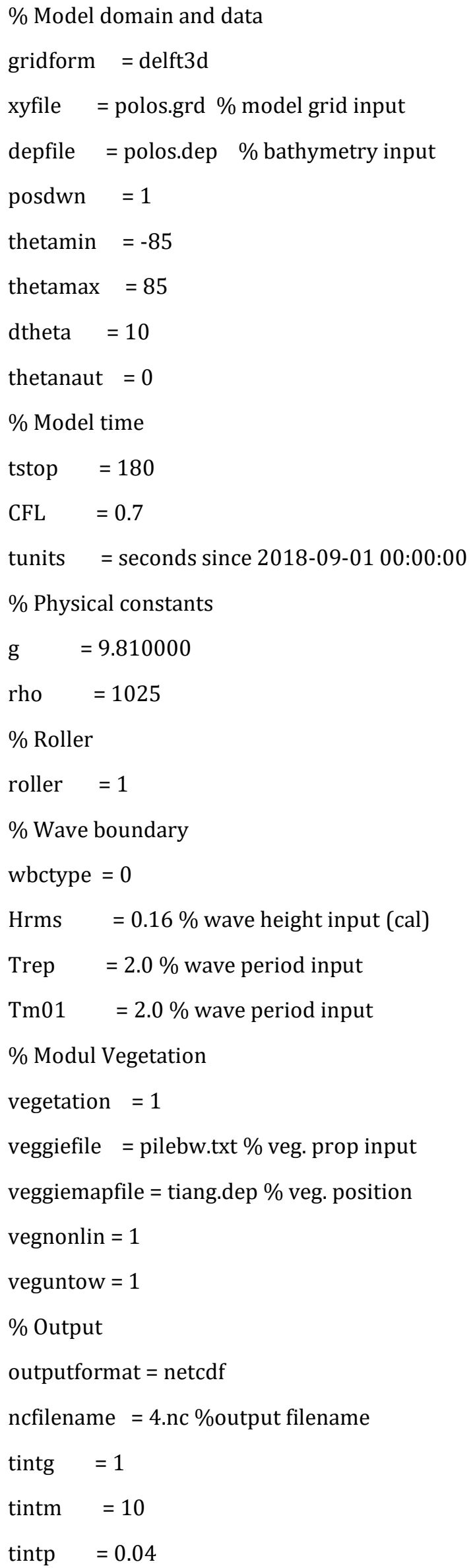


Jurnal Teknik Hidraulik, Vol.10 No.1, Juni 2019: 1-14

nglobalvar = 2
zs
hh $=1$
nmeanvar
zs
npoints $=44$

$20.21 .5 \%$ wave probe 1 position

$21.41 .5 \%$ wave probe 2 position

$22.11 .5 \%$ wave probe 3 position

$30.81 .5 \%$ wave probe 4 position

$30.80 .75 \%$ wave probe 5 position

$31.81 .5 \%$ wave probe 6 position

$31.80 .75 \%$ wave probe 7 position

$32.81 .5 \%$ wave probe 8 position

npointvar $=2$

zs \% output variable

hh $\%$ output variable

\#pilebw.txt (file input for vegetation properties)

This txt. file will call another txt. file named pilebwprop.txt which contain :

nsec $=1 \%$ number of vegetation layer

$\mathrm{ah}=1 \%$ vegetation height

$\mathrm{Cd}=0.7 \%$ drag coefficient

$\mathrm{bv}=0.06 \%$ vegetation diameter

$\mathrm{N}=47.4465 \%$ vegetation density per area 